University of Nebraska - Lincoln

DigitalCommons@University of Nebraska - Lincoln

Faculty Publications - Modern Languages and Modern Languages and Literatures, Department Literatures

June 2002

\title{
Through the Talking Glass: Translucence and Translation in the Condé Museum's Psyche Gallery
}

Russell J. Ganim

University of Nebraska-Lincoln, rganim1@unl.edu

Follow this and additional works at: https://digitalcommons.unl.edu/modlangfacpub

Part of the Modern Languages Commons

Ganim, Russell J., "Through the Talking Glass: Translucence and Translation in the Condé Museum's Psyche Gallery" (2002). Faculty Publications - Modern Languages and Literatures. 14.

https://digitalcommons.unl.edu/modlangfacpub/14

This Article is brought to you for free and open access by the Modern Languages and Literatures, Department of at DigitalCommons@University of Nebraska - Lincoln. It has been accepted for inclusion in Faculty Publications Modern Languages and Literatures by an authorized administrator of DigitalCommons@University of Nebraska Lincoln. 
Published in The Shape of Change: Essays in Early Modern Literature and La Fontaine in Honor of David Lee Rubin, edited by Anne L. Birberick and Russell Ganim. Rodopi: Amsterdam \& New York, 2002. Pp. 53-89. Copyright (C) 2002 Editions Rodopi B.V. Used by permission.

\section{Through the Talking Glass: \\ Translucence and Translation \\ in the Condé Museum's Psyche Gallery}

\section{Russell Ganim}

The forty-four stained-glass windows (dating from 1540-44) that recount the mythological tale of Psyche in Chantilly's Condé Museum present a unique semeiological challenge to scholars. Accompanied by lyric inscriptions of either four or eight lines, the panels reveal an image/text combination that represents a literal example of the Renaissance notion of ut pictura poesis. ${ }^{1}$ These seldom-discussed panels merit inquiry because they reflect certain historic, artistic, and literary trends that illustrate factional and intellectual movements crucial to understanding France of the early to mid-sixteenth century. In its examination of these issues, this essay asks three questions: 1) What is the political significance of the gallery? 2) Why are the panels important in terms of Renaissance aesthetics, and how do they enhance the viewer's knowledge of image-text interaction? And 3) What examples can be given of how pictura and poesis, as they are uniquely presented in the gallery, enrich the narrative process depicted in these windows? In answering the first question, I will argue that the windows represent a political allegory that alludes to the disgrace and exile of their patron, Anne de Montmorency (1493-1567), Francis I's "Constable of France." Montmorency's choice of Psyche lies in the desire to illustrate his struggle via a character who will elicit sympathy in a profound, but discreet manner. Like Psyche, who incurs the wrath and envy of Venus, the Constable falls prey to a powerful woman, specifically, Francis's mistress, Madame d'Etampes, whose jealousy forces Montmorency's departure from the court. With the political statement comes aesthetic commentary as well. Specifically, the Psyche windows illustrate from a structural perspective the Renaissance idea that art deemed "religious" in nature may be considered not merely as a "receptacle of the holy" but as a work of independent, discriminating merit (Belting, Likeness and Presence 458). 
Within this new mentality, a "religious form" such as stained glass, need not necessarily depict a theme one would traditionally find in a church or cathedral. Changes in aesthetics and religion went hand in hand during this time, as Protestant, especially Calvinist, emphasis on the "Word" of God over His "Image" indirectly gave rise to a heightened presence of the word in art throughout the early to mid-sixteenth century. The presence of the lyric inscriptions in the Chantilly windows can be attributed at least in part to the emergence of the word in artistic expression at this time.

To understand the relationship between verba and imago as it exists in the panels themselves, this essay will draw on the literary criticism of W. J. T. Mitchell, the historical analysis of Hans Belting, and the translation theory of George Steiner, Roman Jakobson, and André Lefevere. What these theories have in common is the notion that a certain fluidity exists between sets of signs. In the case of the Psyche gallery, the "hermeneutic motion" (Steiner 296) that exists between word and picture allows for a dynamic exchange between the two principal narrative elements of the panel. Yet, the symmetry between word and image is often only partial, since these modes of discourse sometimes diverge as much as they converge. The poems and windows translate each other, but often only in translucent, semi-transparent ways. Consequently, the meaning word and image convey together is problematic and ambiguous almost as frequently as it is reciprocal. Accordingly, the viewer is required to mediate between pictura and poesis, rendering his/her role more active in determining the significance of the panels, and in shaping the critical debate over the interaction between these means of expression. However, the narrative related by the verba/imago relationship within the panels themselves cannot be fully appreciated without a more global understanding of the historical and critical circumstances in which the windows were created. These general conditions comprise a narrative of their own.

\section{Genesis and Political Allegory}

It is not coincidental that Montmorency's commission of the lyric inscriptions and stained-glass images between 1540 and 1544 overlapped greatly with his first "disgrace" from court, officially beginning in 1541, and ending with Francis's death in $1547 .^{2}$ To understand the political narrative conveyed by the panels, certain facets of Montmorency's life warrant highlighting. Descending from an Ile-de-France clan whose nobility had been certified since the end of the tenth century, Montmorency (named for his godmother Anne de Bretagne) defined himself through wealth, power, and association with the monarchy. A childhood companion of Francis, Montmorency earned the king's respect in battle, fighting in several of Francis's Italian campaigns against Charles V in the 1520s, and helping negotiate the monarch's release from prison as part of the Treaty of Madrid in 1525. The following year, Montmorency was named governor of the Languedoc and "Grand Maître de France," which meant that Montmorency oversaw the royal household, setting the king's schedule and regulating his visits. He became one of the king's chief domestic and foreign advisers, and played a major role in concluding the Peace of Cambrai in 1529, and then in defeating the Emperor in northern Italy and Provence in 1536. After engineering the Peace of Aigues-Mortes with the Hapsburgs in 1538, Francis bestowed the tide of "Connétable de France" upon Montmorency. His reputation as Francis's emissary led to associations with a host of European rulers, among them Charles V, the Pope, and Henry VIII of England. Now bearing the rank of "Constable," Montmorency became the head of all royal armies, and was the king's chief diplomat. The Constable's acquisition of political and military power was matched by his ravenous desire to increase his personal wealth. Through various land acquisitions, Montmorency's already vast revenues multiplied nine times between 1521 and 1561. Even by the time of his first disgrace in 1541, Montmorency had amassed an enormous fortune, making him one of the richest men in Europe, and the second most powerful man in France. ${ }^{3}$

Accumulation of financial, military, and political power begat Montmorency numerous enemies and led to his downfall. As Francis's health began to fail in the late 1530s, the influence of his favorite, Anne de Pisseleu (the Duchess of Etampes), grew to the point where the historian Robert Knecht characterizes her as the court's "supreme dispenser of favours and disfavours" (557). Madame d'Etampes's reasons for trying to remove the Constable were many. First, in her effort to consolidate power with her circle 
that included Cardinals Tournon, du Bellay, and the "Chancellor of France" Guillaume Poyet, Montmorency presented a direct obstacle. Secondly, the Constable gained the support of Francis's second wife, queen Eleanor, the Emperor's sister. Madame d'Etampes despised the Hapsburgs, and had even planned to capture Charles V during an official state visit. More dangerous to the Duchess, however, was Montmorency's extremely close association with the Dauphin Henri and his (and Francis's ex-) mistress Diane de Poitiers, whom she suspected of conspiring to seize the monarchy from Francis. The rift between the Constable and the clique centered around the Duchess became so great as to prompt the visitor Mary of Hungary to describe the situation in the following manner:

As for the government of the court, Madame d'Etampes has more credit than ever. The ... constable is paying court to her; his credit is diminishing each day. He has had angry words with the chancellor (Knecht 396) . ${ }^{4}$

Madame d'Etampes seized the occasion of Montmorency's failure to regain Milan during talks with the Hapsburgs in 1540 to exclude the Constable from foreign policy decisions. His dismissal was assured in June of 1541 during the marriage ceremony of Francis's niece Jeanne d'Albret (daughter of Marguerite d'Angoulême, another adversary of the Constable's), when the king, upon noticing that the twelve-year-old bride was wearing a dress so long and heavy that it prevented her from moving forward gracefully, ordered that Montmorency carry the child to the altar. Humiliated, the Constable obliged, then formally withdrew from court the next day. ${ }^{5}$

What then, is the connection between the political events preceding Montmorency's banishment and the genesis of the Psyche gallery? At the outset, it is important to underscore that patronage of the arts was a key means by which the Constable expressed his clout and affluence. Through Francis, Montmorency's connections with aesthetic expression in France were quite close. After receiving the tide of "Grand Maittre," he was also named superintendent of artistic works. The plans for the restoration of Fontainebleau and Saint-Germain-en-Laye had to be submitted for his approval before renovation began. One possible reason for Montmorency's attachment to art was the effort to soften his reputation as a reitre (Bedos-Rezak 268), or "thuggish soldier" (Oxford 694). More than likely, however, Montmorency, following the king's example, drew the parallel between art and authority. In his many projects, the Constable engaged the services of French School specialists such as Palissy, Goujon, Limousin, and the Clouet brothers, as well as Fontainebleau School artists, among them Cellini, Rosso, d'Oggiono, and Durantino, whose masterpieces adorn Montmorency's chateaux at Ecouen and Chantilly (the Psyche panels were originally designed for Ecouen, then moved to Chantilly in the nineteenth century), his Parisian residences, and the collegial church at Montmorency. As one can imagine, the paintings and sculptures in the castles consisted mainly of family portraits and representations of the Constable's battles. With respect to stained glass, Montmorency's taste for the religious form of the medium found expression at the church of Ecouen, as well as the collégiale at Montmorency, where members of his family are depicted in pious poses as knights of the Order of Saint Michael. The chapel at Chantilly also contains windows, originally designed for Ecouen, that depict the Constable and his family in the principal scenes of Christ's life. Such donor portraits were commonplace during this era, and Montmorency, in the manner of other lords of his birth and wealth, saw these portraits as well as patronage in general as a form of self-representation and selfaffirmation. With respect to stained glass, Montmorency's use of the medium borders on self-deification at the collégiale and the chapel at Chantilly. In the Psyche gallery, however, it becomes a metaphorical means of justifying and elevating himself in the face of a political crisis.

On the surface, very little connects the Constable of France with a postpubescent maiden from mythology. Briefly, Psyche's tale is that of a human princess who raises the ire of Venus through her beauty, then unknowingly beds the God of Love only to attack him and send him fleeing. Consequently, she sets herself on a course fraught with a series of travails that will culminate in a reconciliation with Venus, marriage to Cupid, and her own welcome among the immortals. One could simply argue that Montmorency decided to commission stained glass depicting the Psyche and $\mathrm{Cu}$ pid myth because this theme was popular at the time, having been resuscitated first in 1517 by Raphael in Rome's Famesina loggia, and later in the Brussels tapestries of the 1520s. Despite certain similarities to courtly intrigue, the Chantilly windows in no way constitute a roman à clef, with each character representing someone from the king's inner council. Indeed, the 
most glaring absence is that of a readily identifiable Cupid-like figure, who falls in love with Psyche, intercedes on her behalf, and assures her redemption. ${ }^{6}$

Nonetheless, when taking into consideration broad elements of the plot, as well as the chief themes of the Psyche myth, key similarities emerge. In a general sense, the transposition of the machinations of divine power to the intrigues of Francis's court is easily accepted in view of the French monarchy's appropriation of the "divine right" to rule, as well as the aforementioned tendency of the nobility to deify itself in art. More specifically, however, to answer the question "Why Psyche?" the first step is to ask "Who is Venus?" In light of the vindictiveness and envy with which Venus is portrayed, the correspondence between Venus and Madame d'Etampes becomes clear. The Duchess's status as a conniving "Goddess of Love" is reinforced not only by a politically motivated liaison with Francis, but by her affairs with other high officials such as the Comte de Brissac, Admiral Chabot, and as Knecht notes, with Montmorency himself (557). ${ }^{7}$ The Constable's involvement with Madame d'Etampes renders the historical/ biographical allegory of the windows more personal, and therefore even more plausible. Metaphorically, the seductress "queen" Venus/Madame d'Etampes seeks to ruin Psyche/Montmorency because of a political struggle, and to strike back at a lover who has turned against her. As history bears witness, Montmorency resembles and differs from the Psyche represented in the panels, but particular similarities appear to be more than accidental. A more detailed look at Psyche's character and actions will shed light on the comparisons and contrasts with Montmorency.

Psyche is rejected and punished by the gods, but after her initial (but understandable) distrust of her husband, does not manipulate Cupid or anyone else in retaliation.' She and Venus rival one another, but only as a function of their beauty. Most observers of the panels would conclude that Psyche neither seeks to topple, nor to share power with the goddess. Rather, Psyche aspires to a rightful, but faithful place among the gods as Cupid's wife and, consequently, as Venus's daughter-in-law and subordinate. Similarly, one surprising aspect of Montmorency's exile was his willingness to accept it. While it is true that Montmorency looked to reduce Madame d'Etampes's influence with Francis (and perhaps Psyche's attack on Cupid does translate into some admission of guilt on Montmorency's part), the Constable remained loyal to the king himself during his disgrace. His allegiance is somewhat curious in light of the fact that the Constable's military, financial, and diplomatic connections with other European leaders could have given him leverage against Francis if he had chosen to apply it. Much like the Guise family in the latter part of the sixteenth century, the Montmorencys could have challenged the authority of the Valois dynasty, but, unlike the Guise clan, opted not to do so. What occurs is that Montmorency, like Psyche, complies with the ruler's wishes and offers little resistance in order to prove fidelity. Through Psyche, Montmorency shows not anger toward his adversaries, but a desire to attain a kind of redemption with respect to a higher power.

As a result, one reason why Montmorency commissions the portrayal of Psyche's ordeal, rather than depicting, for instance, the seemingly more appropriate and tempestuous relationship between Venus and Mars, is to illustrate, at least at this point in time, the absence of hostility and the hope of reconciliation. Montmorency I was rehabilitated under Henri II, but for the moment, he selects a feminine, amorous figure to confirm his affection for Francis, and to underscore the respectful, non-aggressive stance he has adopted in response to tension within the monarch's inner circle. The very name of the gallery ( $L a$ Galerie de Psyche, as opposed to $\mathrm{La}$ Galerie de Psyche et de Cupidon) emphasizes that the narrative is to be told from the point of view of the one who has suffered the offense. As there was no real equivalent of Cupid to defend the Constable's cause, what emerges from the gallery's tide, as well as from certain panels of the windows themselves, is a sense of Psyche's, and hence Montmorency's, solitude and abandonment.

Unquestionably, there must have been moments during the Constable's disgrace when he considered himself the victim of superior forces conspiring against him. The selection of a woman to represent Montmorency, however unlikely this may initially seem, underscores what he must have seen as his own persecution. It also renders him more sympathetic in the eyes of the courtly public — among them the Dauphin, Diane de Poitiers, and other supportive nobles - who would have viewed the panels during any one of a number of Montmorency's sumptuous receptions at Ecouen. In 
critical terms, the political conditions under which the windows were produced shapes the understanding of what Erwin Panofsky calls the "iconological interpretation" (38) of a particular work of art. For Panofsky, the concept of iconology basically refers to the comparing of "the intrinsic meaning of the work ... against the intrinsic meaning of the political, poetical, religious, philosophical, and social tendencies ... of the personality, period, or country under investigation" (39). The narrative established by the political backdrop against which the windows are set is important in revealing the work's overall semeiological thrust. From an allegorical standpoint, politics, or res publica, becomes both res poetica and res pictura in that Montmorency's political travails provide, in an indirect and symbolic manner, much of the verbal and imagistic impetus for the gallery. Through verba and imago, politics are transformed, if not translated into art. The link between these three elements is rendered inseparable. Yet, to understand better the political context surrounding Montmorency and the windows' creation, it will be useful to analyze these events within the framework of the "religious and philosophical tendencies" of this era because these trends influenced the aesthetics of Renaissance France, and in turn bore their iconological stamp on the Chantilly panels.

\section{Secularization, the Word, the Image, and Changing Perceptions of Art}

One of the most curious aspects about the Psyche windows is the apparent incongruity between their form and content. While paintings depicting the gods of antiquity were common during the Italian and French Renaissance, stained glass generally remained the province of Judeo-Christian theology. Stained glass with secular themes did gain some currency in France during the early to mid-sixteenth century and was found in private residences. But apart from the Psyche gallery, virtually no examples exist today. The question thus becomes "Why adopt a principally religious structure to convey a profane tale?" While Montmorency's vanity in portraying himself as a demi-dieu déchu offers one answer; the theological and artistic climate in which the panels were created proposes others. Belting claims that even before the development of Protestantism, the secularization of European society that in part characterized the Early Modern had begun to erode the authority of the Catholic Church. Despite the spread of the Reform movement, this secularization continued in such a manner that the influence of religion declined to where, "it ultimately was assigned the segregated area in society with which we are now familiar." (458). To segregate religion necessarily meant a re-evaluation of art, whose subjects and sponsors were normally linked to the Church. According to Belting, what occurred, especially in Catholic circles that still embraced the semeiological value of images, was an altered theory of aesthetics where observers considered religious imagery not only as vessels of the divine, but as "expressions of art" (458), independent of their institutional origin and purpose. Afterward, in some instances, the appreciation of ostensibly "religious" art began to focus less on its thematic, or spiritual import, and more on its technical expertise. This said, it should be remembered that sixteenth-century Baroque art, as it began in Italy and spread to Spain, coincided with the Catholic Counter-Reformation and emphasized the vigor and power of imagery in an overt and aggressive manner. Virtuosity and religiosity went hand in hand. As a result, opinion on the value and purpose of art in the Catholic world was divided, with the general status of the imago complex, if not problematic. Nonetheless, one can affirm that the climate in which art "ceased to be a religious phenomenon in itself," and came to "symbolize the new, secularized demands of culture and aesthetic experience" (458), informs the perception and analysis of the Chantilly windows, especially when seeking the answer to why a palpably nonecclesiastical narrative such as that of Psyche appears in what was a generally religious medium. The windows are a social and historical construct, reflecting the political and artistic conditions of their day. Given the altered state of aesthetics in the first half of the sixteenth century, it is plausible to assert that those who contributed to Montmorency's project no longer felt bound by traditional codes concerning the structure and function of art. Just as painting with a divine theme was no longer regarded exclusively in terms of its metaphysical content, so stained glass, historically an art form reserved for hallowed themes, could follow the trend of secularization and depict legends from mythology or other less sacred domains.

The changing artistic and religious climate of the Renaissance in part explains the presence of lyric inscriptions beneath the images in 
the panels. With Protestantism, and in particular Calvinism, came of course an iconoclastic, often violent response toward Catholic reliance on imagery that was considered gaudy and sacrilegious. Belting suggests that Calvinist disdain of Catholic "idolatry" led to an emphasis on the "Word" as the only real source of divine truth (460). As once-Catholic churches in Geneva were purged of their supposedly fetishistic symbols, plaques on municipal buildings began to appear, introducing what Belting calls an "icon of the word" (461). These "civic inscriptions" (464), which entailed the public expression of texts in a form other than that of the book, gained a political currency that no doubt had an impact on artistic creation as well. In light of the diverse and often conflicting attitudes toward aesthetics during this era, one can assume that the notion of the "icon of the word" did not limit itself to Calvinist milieus. Without question, certain currents overlapped irrespective of their religious and political origins, displaying a kind of "dualism" (465) as expressed through verba and imago. One example Belting cites of the effort to combine word and image in the same artistic work is Albrecht Dürer's well-known 1526 engraving of Erasmus in which the philosopher is shown composing a text while looking at an open book and standing in front of a plaque that makes specific reference to the image, the subject, and the artist (464).

Similarly, the Psyche gallery illustrates the tendency to convey this duality between Catholic primacy of the image, as well as the emerging Protestant emphasis on the word. With respect to Montmorency's religious orientation, it must be remembered that the Constable was a staunch Catholic who died fighting Huguenots during the Wars of Religion. As a result, in no way can the inclusion of octaves and quatrains in the panels be said to represent a kind of silent sympathy with the Reformers. However, given Montmorency's general culture, and more importantly, the vast culture of those who worked for him, it is not surprising that something resembling a Protestant aesthetic, which at that time was becoming a European aesthetic, would find its way into the commission of an enormously wealthy Catholic patron. ${ }^{8}$ Clearly, Montmorency saw the Psyche gallery as a means to call attention to himself. The windows would not only metaphorically relate his political travails, but his singularity as a patron who sponsored works at the creative forefront of their day. If one recognizes the idea that the windows represent a specific social and aesthetic product, it may be argued that the gallery was built in part to suggest that stained glass could be used as a devotional medium of art as well as of religion. In the increasingly secularized world of the sixteenth century, what was now venerated were aesthetics and patronage, along with God.

\section{Translation, Complementarity, and Divergence: Word and Image Interaction}

Explanation of the religious and aesthetic circumstances that led to the combination of words and images still leaves unanswered the question of what cognitive and emotive effects this synthesis elicits from the viewer. The joint depiction of discourse (either written or spoken) and image has, of course, precedents extending past Renaissance Europe. Belting discusses the popular, almost occultist High Medieval tradition of the "speaking image" associated with eastern Mediterranean Christianity that purportedly ascribed powers of speech to shrines, relics, and icons (The Image and Its Public 7). Belief in miracles and magic led to an "affective religiosity" (7) in which, not unlike Ignatian meditation of the Renaissance and Baroque eras, the contemplation of an image led to an emotional, if not discursive response by the meditant in the form of prayer. Certainly, religious stained glass served the same purpose. In terms of the physical juxtaposition of word and image. Belting mentions a twelfth-century imago Crucifixi painted for a monastery adjacent to the Church of the Holy Sepulcher in Jerusalem. This image carried a written addendum that established communication with the beholder, and "appealed to his [/her] sympathy" (6-7). ${ }^{9}$ Within the context of Catholicism, one also notes that in many churches and cathedrals, the Stations of the Cross represented a pictorial image from the Passion, along with a brief textual summary of the particular event depicted. Worshipers also recited prayers at each station, thereby adding speech to the written discourse already associated with the physical image. Indeed, the physical structure and presentation of the Chantilly windows is not unlike that of the Stations of the Cross, in that each verriere (of which there are seven, each with six individual windows), or section-of-glass wall, serves as a kind of stopping point, or lieu de méditation, where the 
observer receives both a textual and pictorial synopsis of the narrative. As in religious art, the beholder casts his/her "individual associations... into the image" (3). Both image-maker and poet deploy various techniques of identification to evoke responses of compassion, sorrow, fear, or reflection, among others. A dialogue thus exists between the windows and the beholder, but the question remains of whether or not pictura and poesis elicit different reactions. Do the images, by virtue of their visuality, appeal more to the affect, while the poems, relying on something as potentially esoteric as the written word, induce more of an intellectual reply? Or do both parts play an equal role in striking the beholder's heart, as well his/her mind?

Mitchell provides a convincing response to this quandary when he discusses the natural inclination of most observers to visualize a written text, as well as to verbalize a picture (42). He holds that there is "no essential difference between poetry and painting" (49), in the sense that they are equal in their ability to transmit signs. The process of ut pictura poesis, then, becomes one of locating "analogies or critical conceits that identify points of transference and resemblance between texts and images" (48). Commonly held notions purporting that painting (or the case of Psyche, stained glass) belongs to the realm of the visible, while poetry inscribes itself within the domain of the invisible become irrelevant. The allusive character of both media bespeaks a semiotic richness whereby particular themes, metaphors, and meanings may be visible or invisible in either mode of expression. The Psyche windows, much like the emblem of the sixteenth century, represent the literalization of ut pictura poesis because poetry occupies a real space within the pictorial frame, not just a conceptual or figurative one. It follows, then, that the observer has virtually no choice but to recognize and ponder the verbal construct every picture suggests. Similarly, the image seemingly issued forth from the poem exists as a material, rather than a virtual, construct. As a result, the performative functions of both modes of expression are inextricably linked to one another. However, in the case of the Psyche gallery, the reciprocity and interaction between picture and lyric inscription does not mean mutual reproduction. Both media are equal in their ability to transmit any given sign, but are not identical as to what they transmit in any given frame. In a partial manner, referents from the images and poetry are repeated or translated through the other medium. There does not exist, to use Stephen Bann's phrase, "complete legibility"
(28) between pictura and poesis. ${ }^{10}$ Within the synoptic structure of the glass/lyric unit, a dialectic arises between clarity and opacity in the narration, and in the roles imago and verba play in the pictorial and lyric chronicle of Psyche's myth. As Walter Melion and Norman Land have shown in their analyses of the engravings of Marcantonio Raimondi and the art criticism Pietro Aretino, respectively, the relationship between ekphrasis and imago is one where word often calls attention to the effects of verba, while the picture can often appropriate the purpose and meaning of the text. ${ }^{11}$ Clearly, in this analysis of the Montmorency windows, the study of ekphrasis, defined by Land as "the verbal re-creation or evocation of a work of art in prose or verse" (xvi), is not an end in itself. Rather, the goal is to see how ekphrasis in the Chantilly panels becomes pictorial in the same manner that the windows' images illustrate an ekphrastic character. Correspondence of pictura to poesis and vice-versa is translucent rather than transparent, just as the very function of the imago and the lyric inscription are fluid rather than fixed within the panel.

Translation theory provides both a language and a critical framework through which the analysis of the text/image dynamic can be better understood, especially in terms of the viewer's role in assigning meaning to the specific panels. Initially, it is important to note that applying the word "translation" to the Chantilly windows does not refer to the Jakobsonian notion of "translation proper, " (Bassnet-McGuire 14) which Susan Bassnet-McGuire describes as:

the rendering of a source language (SL) text into the target language (TL) so as to ensure that (1) the surface meaning of the two will be approximately similar, and (2) that the structures of the SL will be preserved as closely as possible but not so closely that the TL structures will be seriously distorted. (2)

Rather, the term "translation" will be used in the sense of the French term translater, as opposed to the more conventional traduire because the former term implies notions of "transfer" and "relay" (Robert 441), which are crucial to grasping the link between imago and verba in the Psyche gallery. What occurs in this relationship, in a manner similar to linguistic translation, is a kind of bivalence between modes of discourse, or more precisely between literary and artistic "systems," that share key characteristics, to use Lefevere's paraphrase of the Russian Formalists (12). Like traditional translations, the two 
reflect similar referents, but unlike linguistic decoding, the image/text relation does not present one mode that is "modeled on" another. Even though Christiane Noireau's research suggests the poems were composed before the manufacture of the windows, the extent to which the maitre verrier consulted the poems before he cast the panels is unknown. ${ }^{12}$ It should also be noted that no other gallery acted as a model for Montmorency's commission. Nonetheless, there is no doubt that imago and ver$b a$ were intended to be read together in a complementary relationship, as part of the same semeiological homology. In light of the literary and artistic "systems" that comprise the interpretive process, Jakobson's notion of "intersemiotic translation" or "transmutation" becomes relevant because reading the windows requires "an interpretation of verbal signs by means of nonverbal systems" (Bassnet-McGuire 14). ${ }^{13}$ Deciphering the connection between word and image, the beholder engages in the "intersemiotic transposition" from one set of signs to another (15). The "translation" that results is not "word for word," but rather, as in Bassnet-McGuire's analysis of Horace and Cicero, that of "sense for sense," and "figure for figure" (44). Both elements emerge as "quasi-languages" that "translate" into one another as part of the overall exegetic process. Exegesis leads to diegesis as the viewer helps construct the narrative by following the dual depiction of the Psyche myth. Ideas of interpretive movement between discursive codes evoke Steiner's theory of translation as a "hermeneutic motion," defined as the "elicitation and transfer of meaning" (296) between texts. This theory assumes various forms, but the most relevant to the Psyche gallery is that of a movement based on 1) "literalism," or word-by-word correspondence, 2) "faithful but autonomous restatement," and 3) "imitation, recreation, variation, [and] interpretive parallel" (253). Steiner's three techniques can be used as a loose model for the types of word/window relationships most commonly found at Chantilly, which are primarily: 1) reflective, that is, the two components mirror each other in highly symmetrical fashion, 2) supplemental - text and image reinforce one another - but either may add a theme or motif not present in the other, and 3) problematic, in that the image and poem vary and diverge from one another, at times opening gaps in the reading, or posing contradictions, especially within the framework of the entire picture/text narrative. One may add to all these categories situations where the poem may evoke pictorial elements not present in the image, and where the pictura may raise awareness of verbal elements not readily apparent in the lyric inscription. Throughout the gallery, the mimetic dynamic of the word/image interaction changes with each individual panel. A closer look at the panels will reveal the constant flux and reflux of meaning between the components of the signifying whole.

\section{Purity and Penumbra: \\ Depictions of Psyche as a Lover in Window 12}

Psyche marries the God of Love, and is persecuted by the Goddess of Love, but what kind of lover is she? The poems and windows examined in this section will shed light on this question, with the interaction between the two revealing the models of convergence and discrepancy mentioned earlier. Before analyzing the specific inscriptions and images, however, a brief historical discussion of their compositional background will be useful. Originally, the poems were to accompany a tapestry Montmorency had ordered to recount Psyche's life. This tapestry was either lost or destroyed, but nothing is known as to how and when the tapestry disappeared. With the tapestry gone, the Constable commissioned the stained glass for the poems. As they were initially presented to Montmorency, the poems consisted of thirty decasyllabic octaves, the first ten written by Claude Chappuys, the. second ten presented by La Maison neuve (the nom de plume of Antoine Héroët), and the concluding group penned by Melin de Saint-Gelais. While it is unknown as to why three poets were commissioned to write, the choice of Chappuys, La Maison neuve, and Saint-Gelais is not surprising given that all three benefited from high connections with the court and received royal patronage. ${ }^{14}$ These poems are found just below the images in the seven verrières, and take either the form of quatrains, or octaves, depending on the panel. The authors of the poems accompanying the two windows just outside the gallery are unknown. For the most part, the poems resemble each other stylistically, a rather curious fact given that three different men authored them. In large measure, the poems are highly descriptive, performing the function of advancing the narrative in a factual and concise manner. As far as direct appeal to the 
reader/viewer is concerned, one remarks a somewhat distant tone, although there do exist some direct admonitions (poem 12 by La Maison neuve), as well as exclamatory verses (poem 26 by Saint-Gelais), that border on a kind of lyric free indirect discourse. ${ }^{15}$ Generally though, many of the Pléiade techniques of identification such as use of the first person, direct address of the beloved, and apostrophe are missing from the lyric inscriptions. Mostly absent also are Petrarchan conceits, precious language, anaphora, as well as adaptations of certain lyric subgenres such as the blason and the baiser. However, it is through the detailed nature of the language, especially with respect to Psyche's feelings, that the poets seek to establish sympathy between the reader and the protagonist. This language provides a helpful point of entry into the lyric's relationship with the windows.

Most accounts cite the template for the images as the engravings of the Maitre au dé, the alleged son of Raphael's etcher, Raimondi. And indeed, the Raphaelite character of the figures certainly points to this influence. It should be noted that the Maitre au dés engravings are themselves accompanied by poems in Italian. These inscriptions recount the Psyche myth, but the French poems often emphasize different motifs and allusions, rendering them an independent literary work. While the cartoons after which the stained-glass windows were realized are accredited to the Flemish painter Michel Coxie, the identity of the maittre verrier remains unknown. In many cases, the correspondence between the Maitre au dé's engravings and the Chantilly windows is direct, with the former clearly influencing the latter. However, there are several instances where the images in the Psyche gallery represent complete departures from the engravings, constituting new, or independent panels to the narrative. No evidence exists to suggest that these independent panels are based on lost engravings from the same set or are from a different edition. Consequently, several of the windows may be termed "original" in that they have no traceable model. From the standpoint of the poems, it should be noted that Chappuys, La Maison neuve, and Saint-Gelais had access to the Maître au dé engravings, and could have based at least some of their lyric inscriptions on these images, and even possibly on Coxie's designs. The cartoons illustrate the myth from Psyche's point of view, depicting her in a sympathetic manner. Much like that of their lyric counterparts, the Coxie/maittre verrier narrative portrays Psyche as a mortal whose accession to immortality is characterized by human beauty and vanity that transform themselves into more divine notions of humility and obedience to a superior power.

How then, is the text by the three poets to be read within the context of the reproductive prints by Coxie and the maitre verrier, and vice versa? That is, are the poems written about and for the images, or are the pictures designed to highlight the verse? There is no set answer to the question either from a chronological or semeiological viewpoint. What one notices though, is an interaction so sophisticated that at times the barriers between image and text break down to the point where imago acts as ver$b a$ and where poesis takes on many of the functions of pictura. When confronting the question of where to start when viewing the panels, the natural tendency is to begin with the images since they occupy the most space within the frame. Initially, it will be useful to give a general description of the picture, highlighting its major figures, then move to the compositional relevance of the elements portrayed, as well as the trajectory of the eye. Afterward, the poem's overall meaning will be discussed, followed by the ways in which it both reinforces and deviates from the image. Windows 12,13, and 14, accompanied by poems 9 and 10 (poem 10 is divided into two quatrains, and inscribed under windows 13 and 14), furnish clear examples of the degrees of congruity and contrast between the modes, while providing insight into Psyche's character and motivation. This set of windows and poems describes Psyche and Cupid's wedding night, as well as her reaction the following day, and give a good example of what is meant by the "reflective," "supplemental," and "problematic" relationships that occur when comparing verba and imago.

What impresses the viewer about window 12 (Fig. 1) is the luminosity with which the initial encounter between Psyche and Cupid is portrayed. By constructing the window so as to allow a significant amount of light to pass through the two characters, the glassmaker takes certain liberties with respect to Lucius Apuleius's rendition of the original myth. In the Latin tale, the scene takes place completely in the dark, as the couple never sees one another. ${ }^{16}$ Indeed, it is ironic that a narrative in which both literally and figuratively, the central figures are kept in the dark, should be depicted in a medium that 


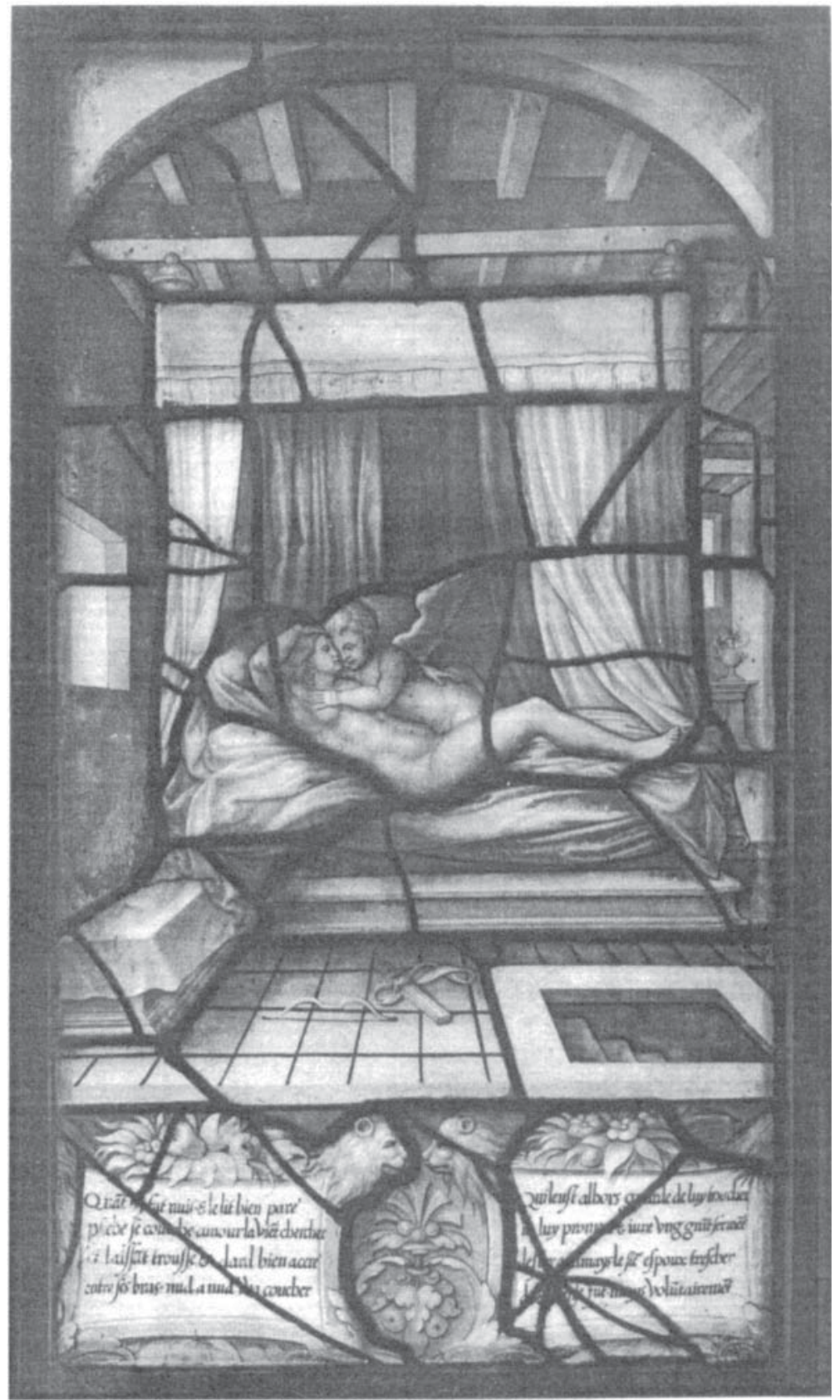

Figure 1 (Photo: Musée Condé, Lauros-Giraudon) depends on light to convey its image. ${ }^{17}$ When the observer passes in front of the panel, however, he/she remarks that light shines the length of the bed and the two nude bodies. The representation of Psyche is especially significant because the voluptuous pose she assumes suggests the ease with which she accepts Eros's overtures. Of note also is the contact between the two faces, whose eyes seemingly meet. Cupid's eyes are definitely open, and while the panel is ambiguous as to whether or not Psyche opens her eyes, the lover's eyes are on the same plane, suggesting a reciprocal gaze. This apparent deviation is of course symbolic, suggesting the comfort, if not the familiarity the lovers share, despite the mystery surrounding their first encounter. The abundance of light becomes an extension of the couple's ardor. To emphasize darkness would have diminished the amorous intensity the artist intended.

In this regard, the poem also distances itself from Apuleius by not dwelling on the penumbra and the fear it engenders in Psyche. Like the maitre verrier, the poet evokes the openness of the rapport between the lovers:

Quant il fut nuyt, et le lict bien paré,

Psyché se couche; Amour la vient chercher,

Et, laissant trousse et dart bien asseré,

Entre ses bras nud à nud coucher.

Qui l'eust ahlors gardé de luy toucher?

Il lui promet et jure grand serment

D'estre à jamais le sien espoux tres cher,

Dont prinse fut, mais voluntairement. (294)

To the extent possible, Cupid presents himself in a frank and sincere manner. The candid and sympathetic nature of his character operates on both a physical and emotional level. Sexually, the God of Love hides nothing, coming to bed, "laissant trousse et dart bien asseré" (1. 3). In the poem as well as the image, nudity represents passion and purity. Verse four, which describes the couple as lying "nud à nud," mirrors the panel exactly, as image and text reflect the natural attraction between the lovers. With respect to translation theory, nuditas becomes a motif transferred from one mode of representation to another in almost literal fashion. Accordingly, the intersemiotic relay of nudity between image and text becomes clear and direct since 
within the synoptic unit of the window, nudity becomes a chief imagistic and verbalistic point of reference.

From an emotional standpoint, the text signals Eros's earnestness in verses six and seven, as the God, "promet et jure grant serment / D'estre à jamais le sien espoux tres cher." ${ }^{18}$ Pledging loyalty before making love, $\mathrm{Cu}$ pid employs words to bolster the seriousness of his intentions. Word reinforces image, not only in terms of the text/image relationship in the panel but with respect to the rapport between Psyche and Cupid themselves. The sense of elegance and safety Psyche presumably perceives, if not "visualizes" from her first night in Eros's bed, is confirmed by the god's spoken oath. For Psyche herself, verbal and pictorial signs converge to provide an impression of psychological and material comfort. ${ }^{19}$ From verse five, the reader discerns that Psyche is attracted to Eros ("Qui l'eust ahlors gardé de luy toucher?)" However, it is not until after the god swears his loyalty that the relationship is consummated at the end of the octave. In large measure, the words Cupid has spoken have shaped the image Psyche has of her husband, and it is this image that leads to their union. Verba has become imago in Psyche's mind, thus prompting her assent to Cupid's desire.

The poem's conclusion continues to build on, or supplement, this sense of security, and, to a certain degree, equality between the lovers by suggesting the consensual nature of the act, "Dont prinse fut, mais voluntairement" (1. 8). While it is clear that Eros "takes" Psyche to satisfy his own desire, the "taking," or "prinse" is voluntary on Psyche's part. Her will coincides with Cupid's because of the latter's fidelity. Chappuys's pun on the terms "prinse" becomes apparent, as he suggests that through Eros's respect of Psyche, and the gallant, respectful way in which he treats her, that the god acquits himself in a regal, if not princely manner. Semantically, Cupid's taking, or "prinse" of the word, illustrates his royal character as a "prinse," thereby rendering his taking ("prinse") of Psyche legitimate. Although the idea of consensuality is implied in the panel by Psyche's highly erotic mien, as well as the absence of any hesitation or resistance on her part, the poem concretizes this notion. As a result, the lyric inscription emphasizes Cupid's valor and majesty in a manner that the image does not. Consequently, at least with respect to the portrayal of Eros, the poem gives more heft to the frame's semeiological charge. To employ the second category of Steiner's theory, Cupid's pledge furnishes a "faithful but autonomous restatement" (253) of the sensual calm Psyche's pose betrays in the stained glass. The restatement of Psyche's assurance is expressed through the poem in that image and text convey a sense of trust that could be considered unexpected given the mystery surrounding the union, as well as Psyche's initial fear that her husband will do her harm.

Nonetheless, the trajectory the eye follows in the stained glass can indicate contradictions in this seemingly peaceful scenario when one takes into account the myth as a whole. The path that begins at the trap door in the lower right corner of the picture, then continues toward the bed and exits through the window, serves both to summarize and foreshadow the narrative. An open trap door with exposed steps alludes to the underworld, and therefore to the potentially dubious and sinister nature of the coupler relationship. Passing just above the stairs, the eye is led toward Cupid's bow and arrows, which become metaphors, respectively, for feminine and masculine sexuality. In turn, the bow and arrows direct the observer's gaze toward Eros and Psyche consummating their relationship. While alluding to passionate union, the bow and arrows also suggest violence within the context of the entire tale. Although violence is not explicitly portrayed in this particular panel, the harm Psyche plans and inflicts upon Cupid becomes the subject of several windows, particularly that of panel 18, which depicts Eros's injury and departure. It is because of this later assault that the God of Love will take flight via the window to the left of the bed. Consequently, while no explicit contradiction between the poem and the text exists in the panel, the hint of a potential split emerges when one considers the events of the overall narrative because imago shows signs of extending past the verba inscribed below it. In this instance, pictura anticipates poesis, and calls for the viewer to analyze the windows in a collective rather than individual context. Within this pictographic framework, then. Psyche's future attack on her husband renders the "translation" of her contentment more difficult to accept. The dialectic between clarity and opacity becomes more prevalent when one considers the tension that exists in panels that convey seemingly different ideas. A more overtly contradictory, or problematic tie between image and text will be examined shortly in the discussion of window 14 . For the 
moment, however, the fluidity and exchange of meaning between pictura and poesis becomes readily apparent when one examines the interdependent nature of this relation within the pictorial and verbal frame. "Hermeneutic motion" between levels of discourse is thus constant, with the viewer him/herself having no choice but to follow, and even develop this movement in order to apprehend the narrative.

\section{Windows 13 and 14: Longing, Waiting, and Signs of Betrayal}

Despite the subtle allusions to violence and rupture that can be read into window 12, the general impression that arises when one asks the question "What kind of a lover is Psyche?" is that she is both passionate and faithful. The next two panels would seem to substantiate this assumption, as imago and verba relay, at least initially, Psyche's desire and loyalty. Nevertheless, the depth of the picturalpoesis relationship causes viewers to question this seemingly favorable portrayal. A primary reason for examining the windows as part of a sequence, rather than an assemblage of discreet units, is to show how "hermeneutic motion" operates not only between image and poem within a frame but between panels within the ensemble of the gallery. Diegesis operates in both a focused and a broad manner, as the "reflective," "supplemental," and "problematic," character of the narrative can be understood within the self-contained image-text unit of a single window, as well as within the context of the pictures and inscription of the panels as a whole.

When examining window 13 (Fig. 2), which portrays Psyche in her chambers the next morning, one is struck by the immediate reciprocity between the image and the poem, which, in this case, consists of a quatrain testifying to Psyche's emotional state:

Puis de dormir, non d'aymer, assouvye,

Le jour venu, Estant Amour en voye,

Elle est des gens invisibles servye,

Et tost s'accoustre, et, entre dueil et joye [.] (295)

One of the major themes evident in both text and image is Cupid's absence. He does not appear in the stained glass, and the poem echoes this notion by informing the viewer that the God of Love is "en voye" (l. 2). Imago and verba thus closely reflect one another, but as the beholder examines both modes of discourse more carefully, it becomes apparent

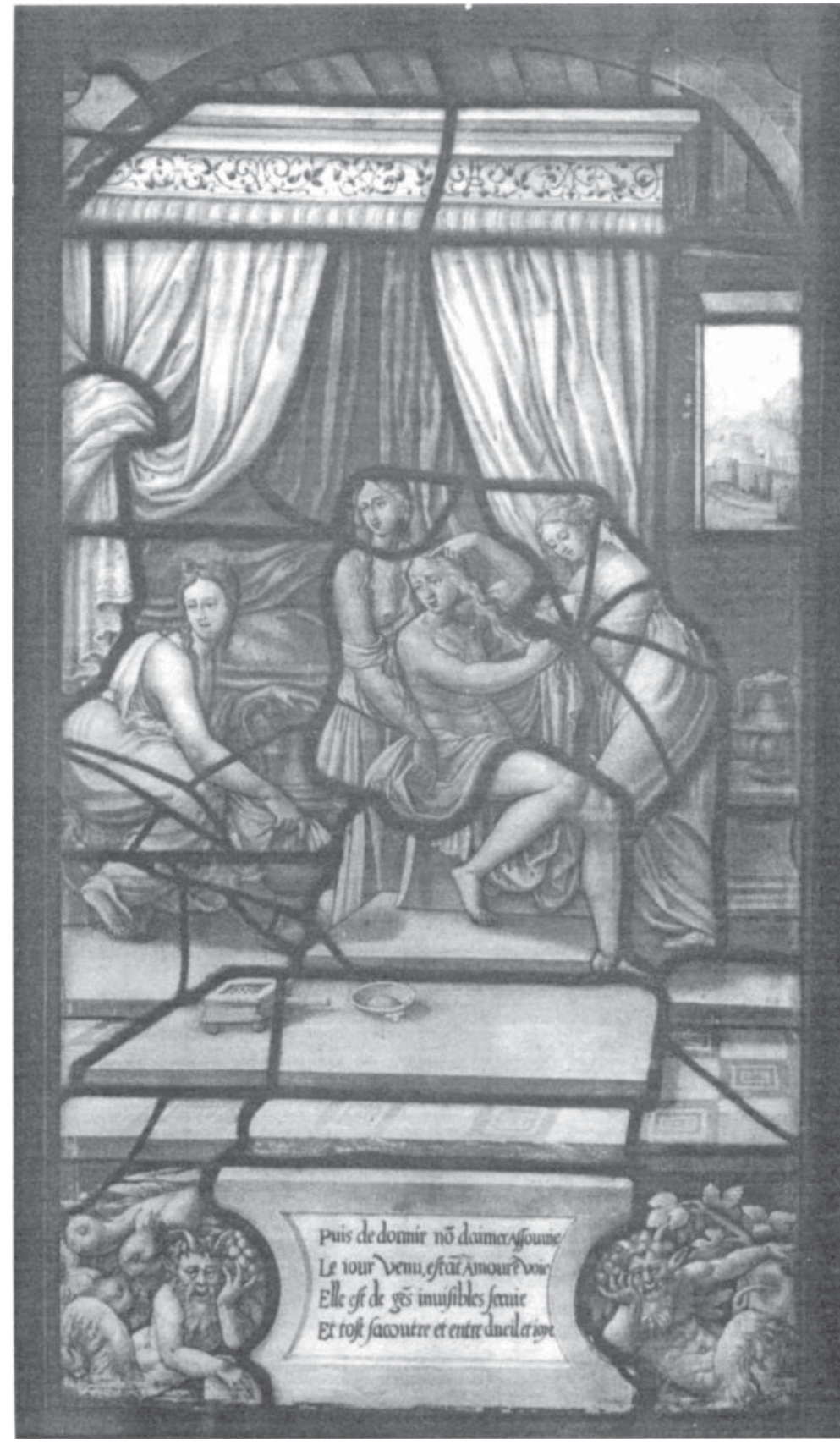

Figure 2 (Photo: Musée Condé, Lauros-Giraudon) 
that the poem sheds a great deal of light on a picture that would otherwise seem relatively straightforward. The image reveals Psyche tending to her morning toilette, assisted by three handmaidens. Her gaze and left hand point toward the left, as if to indicate the direction in which Cupid has gone. In a sympathetic gesture, the handmaidens' glance follows Psyche's, all of which contributes to the sense of absence. Psyche's partial nudity, as well as the presence of the bed, signal the memory of the previous night, underscoring the sensuousness of her character. Nonetheless, the lyric inscription supplements, if not illustrates the picture by informing the reader about Psyche's emotional state, as well as the women serving her.

Psyche looks away in the image, no doubt suggesting loss, but it is the poem that brings to light the duality of her feelings, as she experiences both "dueil et joye" (1. 4) at Eros's egress. Her "joy" is relatively apparent in the image given the sensual nature of the pose she strikes. Yet, while the glass does indicate a sense of absence, and perhaps of yearning. Psyche's face does not indicate "mourning" in the manner found, for example, in window 6 where she is taken to a mountain where Zephyr will lead Psyche to bed her supposedly monstrous husband, or in window 19, which depicts Psyche's deep agony and regret as Cupid takes leave of her. Relying exclusively on the picture, most viewers would find Psyche, half-nude and in front of the bed, curious and awaiting more. Pleased by the previous night's tryst, Psyche eagerly awaits her lover's return. To a significant extent, the function of the handmaidens in the image is to show that Psyche readies herself for the approaching night. In its first verse, the poem reinforces the idea that Psyche seeks additional encounters by telling the viewer that while the craving for sleep has been fulfilled, that for love has not (1. 1). Normally, an observer simply looking at the panel would not inquire about those attending to Psyche before her second night with Eros. Yet, the poem, by indicating that Psyche is served by "de gens invisibles" (1. 3) raises questions about the identity and purpose of the domestics. With respect to the image/text dynamic, the notion that the underlings are invisible poses the question, "To whom are they invisible?" By most assumptions. Psyche does not see them, but the public certainly remarks their presence in the stained glass. Through the poem, the beholder learns the hand- maidens are invisible, but ironically, it is only through their visual representation in the glass that this invisibility takes on any kind of meaning with respect to the narrative. Paradoxically, it is the "invisibility" mentioned in the verba that enhances the visibility of the maidens in the imago. The lyric therefore supplements the picture and, within the dynamic between clarity and opacity, renders the image in the window clearer and more comprehensible. This is so because if the attendants had not been represented in the glass, that is, if they had been truly invisible, their contribution in terms of the image/text dynamic would not be nearly as significant.

From the standpoint of the lyric, the phrase "en voye" in verse two takes on special meaning in that it highlights the general sense of movement in the frame. Cupid has left the castle, and is indeed "en voye." But in the same manner, the viewer's gaze is constantly sent, or "envoyé" between the image and the text. By making the invisibility of the handmaidens visible, the poem is itself "en voye" in that it semeiologically "sends itself" to the picture. If one extends the meaning of the term "en voye" to include the word "voir," as a kind of lyric pun on the expression "en vue," then the poem is also "seen" within the image, thus lending additional visual presence to the frame's verbal construct. Verba thus appropriates certain functions of the imago to the extent that the inscription explains and accounts for the existence of particular elements of the pictura.

Ostensibly, the maidens' existence is invisible, but within the pictorial narrative of the gallery, they must somehow appear in order for their existence to be verified. One way of tackling this paradox is to claim that much like the presence of angels or demons in religious paintings whose existence is more allusive than real, the servants in the panel occupy a kind of virtual, immaterial space. As such, the maidens have a kind of metapresence, suggesting that they belong to the realm of the divine, or the near-divine. Thematically, the question then becomes whether or not this ethereal presence is benevolent or wicked. Psyche's internal division between "mourning" and "joy" carries new meaning when read within the totality of the narrative. The grief Psyche feels at Cupid's momentary departure pales in comparison to the loss she will experience after the disaster of the second encounter. If the handmaidens prepare Psyche for what will become an overwhelming sorrow, then they represent the agents of 
Venus, whose jealousy is anthropomorphized two panels later by Psyche's sisters, who distort their envy to the point of provoking Psyche to kill Eros. If, however, the domestics' role is to aid their mistress in enjoying what will be Psyche's last night with her lover for a long time, they consequently stand for Cupid, and display the affection he holds for his bride. At this point in the tale, the narrative elicits both analyses, rendering "invisible," or unpredictable, any definite answer. As it is, however, both the frame's text and image, despite their initial tendency to portray Psyche as generally content, carry the potential to highlight her vulnerability. Her nudity, which on one level bespeaks her desire, now intimates the precariousness of her situation, as her exposed body is surrounded by forces she neither sees nor understands. It is thus Psyche's fragility that becomes visible to the public.

The presence of the "invisible" servants suggests a connection to the political allegory depicted in the windows. Exposed and surrounded, Psyche/ Montmorency becomes vulnerable to the stratagems of Venus/Madame d'Etampes who clandestinely applies her power through subordinates. Likewise, the Cupid figure, perhaps representing the Dauphin, sends his lieutenants to do his bidding in order to prepare the reunion. Consequently, the invisible handmaidens represent an implicit commentary on the status and function of divine and royal power, both of which are often exercised covertly, with unforeseeable outcomes for those falling under their rule.

Within these two panels, while the correspondence of meaning between verba and imago vacillates between clarity and opacity, the two generally converge in a discernible manner. However, in the next panel, a distinct contrast emerges, illuminating the occasional dissonance between the two modes of representation. At first glance, the poem and the general image of window 14 (Fig. 3) seem reassuring about Psyche's future. The viewer sees a regal Psyche dressed and coiffed, sitting on a throne-like chair awaiting her "prinse," Eros. In much the same manner, the poem invokes the tranquility and stability of Psyche's love:

Compte à par soy les biens qu'Amour envoye,

Et se mainctient sur toutes bien heurée

Croyant qu'Amour jamais ne se desvoye

Et que la foy est ferme et asseurée. (295)

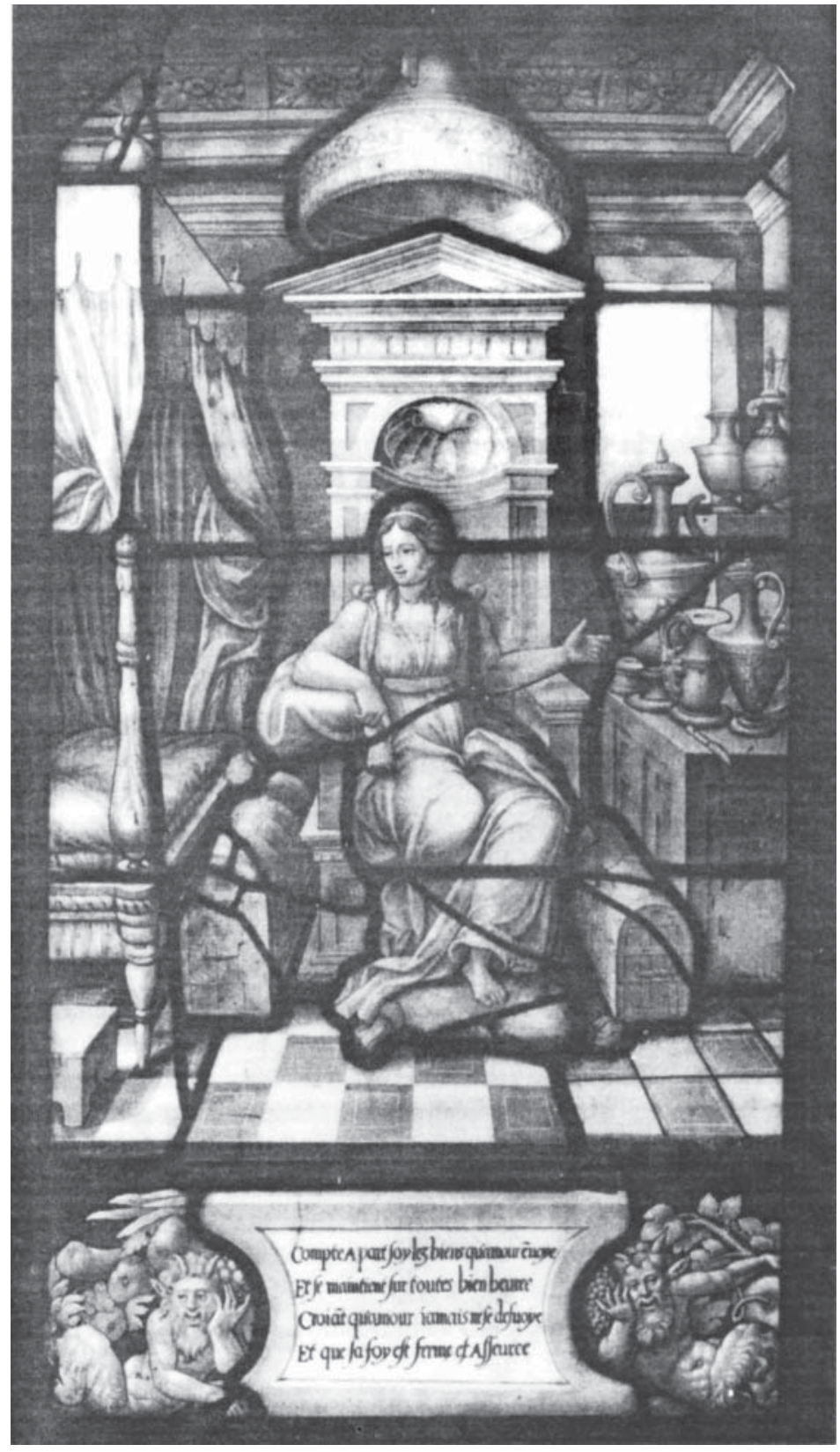

Figure 3 (Photo: Musée Condé, Lauros-Giraudon) 
As in the previous poem, the reader learns of Psyche's emotional state. The inscription's last two lines convey Psyche's complete "faith" in Eros, a belief that, for the moment, appears unshakeable. Nonetheless, from the standpoint of the poem's concordance with the image, the knife resting on the bureau to Psyche's left becomes problematic. The knife, well within Psyche's reach, prefigures, to a greater extent than the bow and arrows in 12, Psyche's attempt on Cupid's life four panels later. As a symbol of masculinity and violence, the knife shows the degree to which Psyche has been "penetrated" by Eros. The penetration is both physical and emotional, but will become pathological, as Psyche is internally lacerated by doubt and jealousy to the point where she must vent this torment by slashing Cupid. Taking Eros's act from him, she will do the piercing, but to a malevolent end, thus becoming the monster she wrongly supposes her husband to be. Because of the knife and what it portends, a temporal and thematic disjunction arises between the written and pictorial discourse since the poem suggests succor in the present, while the stained-glass image hints that the felicity will soon end. Given that no model can be found for this picture in the Maître au dé engravings, it is tempting to suggest that the glassmaker saw an opportunity to make a subtle deviation from the poem and did so knowing that he would render the text/image relationship more challenging to the beholder. Although no historical proof exists for this assertion, it is. clear that from a hermeneutic standpoint, the discrepancy in window 14 requires the observer to propel his/her interpretation forward to grasp the whole of the narrative's meaning. While the divergence between imago and verba is only momentary, and focuses on a single visual motif, the viewer comes to understand that the negotiation between poem and image involves a translation and analysis of signs that go beyond the relatively static frame of an individual panel.

From the standpoint of the lyric and pictorial narrative, it is through the knife that Psyche makes her most significant imprint upon both the windows' text and the image. By using the knife on Eros, Psyche figuratively engraves the imago and inscribes the verba that become an integral part of the chronicle depicted in the gallery. With respect to the idea that within these parallel modes of discourse one element can assume the function of the other, one ones a slight variation within this particular frame because the motif of the knife alludes both to the verbal act of writing while self-referentially reinforcing the imagistic process of cutting and engraving. In effect, the dynamism of transposing verbal and pictorial signifiers across time and space is what leads to the translucence of the reading process. Clarity between words, images, and the functions they perform can only be partial when interpreting the Psyche gallery not only because the panels must be read collectively rather than individually but also because the word becomes part of the pictorial process, just as imago often becomes inseparable from the semeiological purpose and structure of verba. Nonetheless, the holism of the windows alludes not only to the fact that most panels allude to other panels both pictorially and verbally, but also to the multiplicity of narrative registers - political, aesthetic, and textual - that must be deciphered within the unusual format of stained glass. Herein lies the problematic character of the gallery, rendering it exceptional as an iconographical and iconological product of its era.

\section{Conclusion: Iconoclasm and Reinvention}

Given the iconological novelty and significance of the windows, one logical question to ask is how the Psyche gallery reinterprets the medium of stained glass. The answer to this question is in part revealed by briefly examining the form and function of religious stained glass and then comparing this purpose to that of the Chantilly panels. Belting views the windows of the Gothic period as hegemonic, conveying a single message through a structure meant to illustrate a "pregiven world system" (The Image \& Its Public 16). More precisely, he adds:

The cathedral window, though transparent, was a closed field whose arrangement was no less important in its total content than that of each individual pictorial unit. (16)

The concept of "total content" refers to the integrative nature of the viewing experience, but also conveys the idea that when the windows are observed together in a cathedral, their purpose is to overwhelm the beholder with the totality of divine majesty and grandeur. In view of this analysis of Gothic stained glass, it becomes apparent that in choosing a secular topic and in adding a written narrative to the windows, those responsible 
for the Psyche gallery, whether they did so consciously or not, expanded the parameters of the form. The revised aesthetics of the period opened perspectives in this "closed field," and challenged the artistic (and therefore social) values of a world system in which stained glass had been assigned a specific, relatively unchanged function.

Through the lyric narrative, the interpretive possibilities of the medium became enlarged, if not more "transparent" in that the windows could now provide allusions, questions, and answers that extended and deepened the reading experience traditionally associated with this mode of discourse. To a certain extent, Montmorency's commission of the glass can be seen as a manifestation of license and power in the artistic realm. This is so not simply because he was a man of means who could afford the luxury of patronage but because the sponsoring of these pictures and poems represents in a subtle usurpation of the authority of the image, especially in stained glass. By ordering a series of panels on a mythological theme to tell the story of his political exile, Montmorency claims the medium of stained glass as his own. The function, subject, and location of the form are reappropriated. Montmorency, perhaps in spite of himself, emerges as an iconoclast as he overturns basic conventions of the genre. Living in an iconoclastic epoch such as the Reformation, Montmorency and those in his employ could only be affected by the different conceptualizations of the image going on at the time. Iconoclasm, as Alain Besançon suggests, evokes as much the reevaluation and adaptation of images during eras when the value of imagery is called into question as it does their basic destruction (9-11). Accordingly, a kind of iconoclasm exists in the Chantilly windows because Christian imagery has been removed from what was at the time a decidedly Christian means of expression. ${ }^{20}$ Stained glass now depicts pagan gods, and, allegorically, royal power. No longer, at least in this case, does glass imagery embody the divine persona of Christ. More importantly, with the inclusion of a poetic narrative, the aesthetic independence or "supra-individuality" (Belting 16) of the image within stained glass has now been compromised in that imago must be interpreted along with other forms of intellectual expression such as verba. The semeiological primacy of the image is challenged in a medium that almost exclusively relied on the pictura to convey its meaning. Consequently, the gallery's windows are recast as part of the transforming image of art and literature during the Renaissance; and this recasting demonstrated that even the most traditional of media and patrons could reflect the dynamism and innovation of the day.
[Pages 81-83 contained the plates (Figures $1-3$ ), which have been moved to follow pages 69,73 , and 76 in this edition.] 


\section{Notes}

1. I would like to thank the University of Nebraska Research Council for funding this study. Special thanks go to Françoise Gatouillat and Michel Hérold at the Stained-Glass Division of the Ministère de la Culture in Paris, to Amèlie Lefébure, Collections Curator of the Condé Museum, and to Anne Hubrecht of the Agence Giraudon, Paris. Warm thanks are also in order for Charles Palermo who offered many useful insights, and to Nicole Leapley for her logistical help.

2. Montmorency's "second disgrace" took place in 1559 after the death of Henri II, when both he and Diane de Poitiers were effectively removed from power by the Guise family.

3. An excellent summary of the power and wealth Montmorency held under Francis can be found in David Potter's A History of France, 1460-1560, 203-04. A second useful reference is Arlette Jouanna's La France du XVI siècle, $1483-1598$.

4. In his Autobiography, Benvenuto Cellini also mentions the sway Madame d'Etampes held with Francis, as well as her rancorous temperament. He describes her jealousy over not being the first to hear of the artists plans for Fontainebleau in the following manner:

That evening, when she heard the course of events from the King's own lips, it bred such poisonous fury in her breast that she exclaimed with anger, "If Benvenuto had shown me those fine things of his [i.e., the models for Fontainebleau], he would have given me some reason to be mindful of him at the proper moment." The King sought to excuse me, but he made no impression on her temper. (309)

5. See also Albert Willox's account of Montmorency's fall, in Anne de Montmorency, Connétable de France, 108-13. Another useful source is Marc Blancpain's Anne de Montmorency, Le Tout-Puissant, 1493-1567, 100-06.

6. Later in the article, I argue that certain similarities exist between $\mathrm{Cu}$ pid and the Dauphin Henri II. However, this similarity applies only in a limited, figurative sense within the narrative of the windows. Historically, the Dauphin did little to counteract Madame d'Etampes's treatment of Montmorency. The Constable was reinstated only after the death of Henri's father, and the subsequent demise of his mistress.

7. Originating from political interest rather than natural inclination, this brief affair shows the lengths to which both parties would go in order to extend their influence.

8. Research into Montmorency's library shows that the Constable was aware of Reformist discourse. Francis Higman asserts that a reproduction of L'Oraison $d u$ Jesuchrist, a major early sixteenth-century work on Protestant theology, was found in the Abbey of Saint-Germain-des-Prés, bearing the Montmorency coat of arms. Higman suggests that the reproduction may have been commissioned by the Constable at the beginning of the Reform movement, but was relegated to the
Abbey's basement once the document had been declared heretical in 1531. Consult his article in BHR 53.2 (1991): 415-18.

9. The text reads, Aspice qui transis quia tu mihi causa doloris / Prot te passus ita, pro menoxia vita. Also consult page 288 in Belting's The Image \& Its Public.

10. Here I use Norman Land's quote from Bann's The True Vine.

11. See especially Land's chapter on Aretino in The Viewer as Poet: The Renaissance Response to Art. Melton's work is in progress. I am indebted to his remarks at the 1998 Sixteenth-Century Studies Conference in Toronto.

12. Noireau states, "Le manuscrit [des poèmes] fut composé vers 1540, et offert au Connétable." (188). It should be noted that Noireau's unpublished thesis, entitled "Le mythe de Psyché: Recherches Iconographiques," represents the most extensive work on the gallery to date. Her study focuses on the evolution of Psyche's image, comparing and contrasting the Chantilly Psyche with those that preceded it. Noireau's art historical approach also traces the presence and development of attendant motifs in the panels. While Noireau does mention, and occasionally cites the poems, she generally views them as secondary to the pictures, granting them relatively small importance in terms of the panels' semeiological thrust. See also her article, "Les Amours de Psyché de Cupidon," in La Peinture des Passions de la Renaissance à l'Âge classique, 160-67.

13. See Jakobson's article, "On Linguistic Applications of Translation," in R. A. Brower, (Ed.), On Translation, 232-39.

14. In 1521, Chappuys entered the royal household as clerk and sommelier, then in 1533 became a valet to Francis I, and later his librarian. In 1536, he was named "doyen" of the Rouen cathedral, where he received Montmorency's direct support. La Maison neuve's father bore the title of "secretary" to the Duke of Orleans, while his brother held this position with Francis. In 1524, La Maison neuve himself came under the protection of the House of Navarre. Saint-Gelais was an ordained a priest who became Henri II's chaplain and librarian. He took over stewardship of the Fontainebleau library in 1544. See also pages 186-87 of Noireau's thesis.

15. These poems, and all lyric inscriptions referred to in this article, are taken from Noireau's transcriptions of the original manuscript located in the Condé Museum, MS XIV H21, feuillets 194. Page numbers refer to Noireau's thesis. Poems 12 and 26 read respectively:

(12)

Qui recevez amoureuses doulceurs

Et les loyers d'un labeur enduré,

Ne vous fiez en freres ny en seurs,

Ny en conseil d'un amy perjuré.

Voyez les seurs, de visaige asseuré,

Faindre qu'Amour est serpent deshonneste;

Psyché le creut, et de cueur conjuré

Delibera de luy trancher la teste. (295) 
Ah! comme il nuyt d'estre trop curieuse! Psyché, pensant accroistre sa beaulté, Ouvre la boiste, ou peste furieuse

Estoit enclose, et somme et cruaulté;

Et si ne fust la grande loyaulté

De Cupdio, qui la reliefve en voye,

Elle mouroit; mais ayant rebouté

Les maux au vase, à Venus la renvoye. (300)

16. This version appeared in the second century C. E., as part of Apuleius's Metamorphoses, also known as The Golden Ass. Apuleius depicts the scene in the following manner:

Nec quemquam tamen illa uidere poterat .... Tunc uirginitati suae pro tanta solitudine metuens et pauet et horrescit et quouis malo plus timet quod ignorat. iamque aderat ignobilis maritus et torum inscenderat et uxorem sibi Psychen fecerat et ante lucis exortum propere discesserat.

She could see no one.... Then, all alone as she was fearing for her virginity, Psyche quailed and trembled, dreading more than any possible harm, the unknown. Now there entered her unknown husband; he had mounted the bed, made her his wife, and departed before sunrise (Kenney 52-53)

Of note also is the absence of speech between the lovers. In the French and Italian poems depicting this scene, Cupid swears his fidelity.

17. I am indebted to Anne Birberick for this observation.

18. As mentioned in the previous note, the Italian inscription accompanying the Maître au dé engraving (number nine in the collection, and also housed at the Condé Museum) includes Cupid's oath of fidelity. The final couplet reads:

Giurando lei per unica sua sposa,

Ó felice, ó gentil coppia amorosa.

I thank Marian Rothstein for her suggestion that this scene represents a clandestine marriage ceremony. As Professor Rothstein points out in her article, "Clandestine Marriage and Amadis de Gaule" the practice of secret wedding vows was quite common in mid-sixteenth-century France. These marriages were often recognized as legitimate until changes in social and religious attitudes signaled their decline by the end of the century. Ironically, in 1556, Montmorency's eldest son François, who had been betrothed to Henri II's daughter Diane de France, was involved in a dispute over a prior clandestine marriage to Jeanne de Hallevin. See The Sixteenth Century Journal 25.4 (1994).
19. One remarks that Psyche has spent a significant amount of time in the palace beforehand, having been prepared for the evening by Cupid's servants. Poems 7 and 8, windows 9-11, and the fifth book of the Metamorphoses all attest to a period of acclimation in which Psyche becomes impressed with her luxurious surroundings.

20. It is essential to point out that the simple presence of mythological themes in and of themselves, especially during the Renaissance, is not iconoclastic. As Besançon indicates, classical mythology served to reinforce Catholic doctrine during this time (233-34). What is "iconoclastic," however, is Montmorency's erasure of traditional Catholic imagery from stained glass, and the subsequent use of the medium to express his personal travails.

\section{Works Cited}

Apuleius, Lucius. Cupid and Psyche. Ed. E. J. Kenney and P. E. Easterling. Trans. P. E. Easterling. Cambridge: Cambridge UP, 1990.

Bann, Stephen. The True Vine: On Visual Representation and the Western Tradition. Cambridge: Cambridge UP, 1989.

Bassnet-McGuire, Susan. Translation Studies. London: Methuen, 1980

Bedos-Rezak, Brigitte. Anne de Montmorency: Seigneur de la Renaissance. Paris: Editions Publisud, 1990.

Belting, Hans. Likeness and Presence: A History of the Image Before the Era of Art. Trans. Edmund Jephcott. Chicago \& London: The U of Chicago P, 1994.

. The Image \& Its Public in the Middle Ages: Form and Function of Early Paintings of the Passion. Trans. Mark Bartusis and Raymond Meyer. New Rochelle, NY: Aristide D. Caratzas, 1990.

Besançon, Alain. L'image interdite: une histoire intellectuelle de l'iconoclasme. Paris: Fayard, 1994.

Blancpain, Marc. Anne de Montmorency, le tout-puissant. Paris: Editions Tallandier, 1988. 
Cellini, Benvenuto. The Autobiography of Benvenuto Cellini. Trans. J. Addington Symonds. New York: P. F. Collier \& Son, 1910.

Corréard, Marie-Hélène, and Valerie Grundy, eds. The Oxford-Hachette French Dictionary. Oxford: Oxford UP, 1994.

Higman, Francis. "Farel et Luther dans la bibliothèque d'Anne de Montmorency?" Bibliothèque d'humanisme et Renaissance 53.2 (1991): 415-18.

Jakobson, Roman. "On Linguistic Aspects of Translation." On Translation. Ed. R. A. Brower. Cambridge: Harvard UP, 1959.

Jouanna, Arlette. La France du XVIe siècle, 1483-1598. Paris: PUF, 1996.

Knecht, Robert. Renaissance Warrior and Patron: The Reign of Francis I. Cambridge: Cambridge UP, 1994.

Land, Norman. The Viewer as Poet: The Renaissance Response to Art. University Park, PA: The Pennsylvania State UP, 1994.

Lefevere, André. Translation, Rewriting, and the Manipulation of the Literary Frame. London \& New York: Routledge, 1992.

Mitchell, W. T. J., Iconology: Image, Text, Ideology. Chicago \& London: The U of Chicago P, 1986.

Noireau, Christiane. "Le Mythe de Psyché: Recherches iconographiques." Diss. Université de Picardie, 1987.

—_. "Les Amours de Psyché de Cupidon." La Peinture des Passions. Ed. Bernard Yon. Saint-Etienne: Publications de l'Université de SaintEtienne, 1995.

Panofsky, Erwin. Meaning in the Visual Arts. Garden City, NY: Doubleday, 1955.

Potter, David. A History of France, 1460-1560: The Emergence of a Nation State. London: Macmillan, 1995.

Rey, Alain, ed. Le Grand Robert de la langue française. $2^{\text {nd }} \mathrm{Ed}$. Vol. 9. Paris: Dictionnaires Le Robert, 1987.

Rothstein, Marian. "Clandestine Marriage and Amadis de Gaule: The Text, the World, and the Reader." The Sixteenth Century Journal 25:4 (Winter 1994): 873-86.
Steiner, George. After Babel. London: Oxford UP, 1975.

Willox, Albert. Anne de Montmorency: Connétable de France. Paris: La Pensée Universelle, 1995. 